\title{
Perspectives
}

\section{Content-Based Instruction in EFL Contexts: Considerations for Effective Implementation}

\author{
Yuko Goto Butler \\ University of Pennsylvania
}

Recently, there has been growing interest in content-based instruction (CBI) in foreign language education, particularly in English as a foreign language (EFL) education. However, there are a number of challenges for successful implementation of $\mathrm{CBI}$ in EFL contexts, and its implementation therefore needs to be carried out with careful consideration and preparation. Based on a review of previous studies as well as the author's observation of various CBI classes in EFL contexts in East Asia, this paper identifies factors that influence the effectiveness of CBI including: (a) program setting and curriculum, (b) characteristics of teachers, (c) characteristics of learners, and (d) resource availability. The paper concludes with a series of suggestions for the successful implementation of CBI in EFL contexts, with particular emphasis on the implementation of CBI in East Asia.

近年、外国語としての英語教育環境下（EFL）で、コンテント・ベース教授法 （CBI）に対する関心が高まっている。しかし、EFLにCBIを導入するには 解決すべき課題も多く、効果的な導入には、慎重な検討と周到な準備が不 可欠である。本論文では、C B I に関する先行研究や、筆者自身の東アジア 諸国での多種にわたるCBI導入ケースの観察に基づき、以下の 4 点をCBIの効果を左右す る要因として指摘する。すなわち、（a）プログラムの施行状況とカリキュラム、（b）教 員の特徵、（c）学習者の特徵、（d）資源サポートのありかたである。これらを詳細に分 析し、主に東アジア地域に焦点を絞りながら、CBIを効果的に導入するにはどうしたらよ いかについて具体的な提案を行う。

JALT Journal, Vol. 27, No. 2, November, 2005 


\section{The Growing Interest in Content-Based Instruction (CBI) in EFL Contexts}

A high school that emphasizes foreign language education in China has introduced CBI into part of its curriculum. A Chinese teacher of chemistry delivered his lecture in English to his $10^{\text {th }}$ grade students. He showed a PowerPoint slide in English and gave each student a detailed handout written in both English and Chinese. He first explained chemistry concepts in English and then repeated them in Chinese. The students responded almost exclusively in Chinese to the teacher's bilingual questions. Students who were sitting in the back of the classroom struggled with the chemistry problems and only consulted the handout written in Chinese rather than the English one.

At another high school in China, a U.S. teacher who had originally been hired as an English teacher was recently asked to teach biology in addition to English. She was a replacement for a local biology teacher who had been asked to teach biology in the school's newly introduced "bilingual program." The students and parents complained that the Chinese biology teacher had insufficient proficiency in English to teach biology in English, and the principal decided to ask a native English-speaker to teach the class instead. The U.S. teacher was nervous: she was a recent graduate from college with a psychology degree and had no teaching experience, either in English or biology.

A Korean elementary school teacher told her 5th grade English class, "Let's make kimpa today!" Kimpa is rice rolled in dried seaweed, and is a common food in Korea. All the boys and girls wore aprons and were divided into small groups. Each group was given cooking utensils (pots and pans), vegetables, seaweed, salt and water. The teacher demonstrated how to make kimpa while explaining the process in English. However, the process of making kimpa is quite straightforward. There was lots of excitement in making and eating kimpa in class, and many exchanges were delivered in Korean among the children, but little attention was paid to the teacher's English input.

Recently there has been significant global interest in CBI (Stoller, 2004), particularly in English education in countries where English has traditionally been taught as a foreign language (EFL), as well as in English-as-a-second-language (ESL) contexts (Davies, 2003). There are 
numerous case studies that describe how CBI has been implemented in various educational contexts. However, controlled empirical research on CBI is still very limited. The scarcity of empirical studies on CBI is particularly evident at the primary and secondary school levels in EFL contexts, despite the growing popularity of CBI at these levels. As the three episodes described above illustrate, in East Asia many of the implementations of CBI have so far appeared to be based on trial and error, and CBI is often implemented without careful consideration of either its purpose or effectiveness in a given context.

This paper is based on a review of studies on CBI as well as observations of over $30 \mathrm{CBI}$ classes at the elementary and secondary school levels in East Asian EFL contexts (China, Japan, South Korea, and Taiwan). Its purpose is to discuss a number of factors that influence the successful implementation of CBI and to suggest conditions and considerations that are necessary for the effective implementation of CBI, specifically in East Asian EFL contexts.

There is one clarification worth noting: although the distinction between ESL and EFL may not be clear cut in certain regions (e.g., in parts of Europe), this distinction has important implications for English teaching and learning (Strevens, 1992) in a number of regions, including East Asia.

\section{What is CBI?}

CBI is defined as "the concurrent teaching of academic subject matter and second language skills" (Brinton, Snow, \& Wesche, 2003, p. 2). By providing students with authentic, meaningful academic contexts, it aims to develop both the students' language and their content knowledge. In addition, some authors include the development of academic learning skills as one of the aims of CBI (Chamot \& O'Malley, 1994). In CBI, language is not merely the object of learning, but also the means for negotiating meaning, organizing information, and acquiring content knowledge.

$\mathrm{CBI}$ has been supported by a number of theories in second language acquisition. In CBI, students have the opportunity to be exposed to meaningful and comprehensive input in context, which is considered to be an important element for language acquisition (Krashen, 1985). $\mathrm{CBI}$ also provides students with opportunities to negotiate meaning and to exercise productive language skills through which they also can pay attention to forms as well as meaning. Such "comprehensible output" has also been suggested as being an important aspect of CBI (Swain, 
1985, 1993). Cognitively-demanding tasks in CBI help students develop Cognitive Academic Language Proficiency (CALP), which is a key to their academic success (Cummins, 1992).

The cognitive skills and learning strategies that are incorporated into CBI are also supported by a number of educational and cognitive theories in principle. In CBI, teachers are asked to provide students with meaningful and coherent information through various kinds of instructional strategies such as visual aids, conceptual maps, and analogies. By doing so, CBI should help students connect new knowledge with their existing knowledge and schemata, thus enhancing their learning (e.g., Anderson, 1990; Armbruster, 1996). CBI facilitates students' higher-order thinking skills and motivation by providing them with cognitively challenging content materials and tasks. In sum, CBI aims to promote integrated development of students' language competence and content knowledge, and it has been supported by a number of theories from different academic disciplines.

\section{Types of CBI}

CBI has been implemented in various forms across educational settings. As the table in the Appendix indicates, CBI is found in English programs, bilingual programs, foreign language programs, heritage language programs, and other programs across grade levels. Some programs emphasize the students' language development more than content learning (language-driven approaches), while others put stronger emphasis on helping students acquire content learning by providing various types of linguistic and cognitive assistance (content-driven approaches) (Met, 1998). Davison and Williams (2001) mapped different types of CBI approaches on a continuum between language-focused and content-focused approaches. Such variability in the implementation of $\mathrm{CBI}$ is one reason it may be difficult for teachers and policy makers to understand the purposes and effectiveness of CBI.

\section{Factors that Influence the Success of CBI}

There is much evidence supporting the effectiveness of some of the more successful CBI implementations (e.g., Kasper, 1997 and Pally, 2000 for college-level ESL implementations; Wesche, 2001 for Canadian immersion programs). However, the effectiveness of CBI has not always been confirmed (Willis, 1997, as cited in Willis, 1998). The integration of 
language and content remains an ongoing issue (Mohan, 1986). Echevarria, Vogt, and Short (2004) argue that CBI does not work for everybody. The potentially negative effects of CBI implementations may include: insufficient understanding of content knowledge (March, Hau, \& Kong, 2000), insufficient improvement in L2 (Langman, 2003; Pica, 2002), increased stress for both teachers and students (Ryding \& Stowasser, 1997), and the substantial investment of time and energy by both teachers and students that CBI requires (Stryker, 1997). The effectiveness of CBI appears to be influenced by a number of factors including: (a) program setting and curriculum, (b) characteristics of teachers, (c) characteristics of learners, and (d) resource availability. These factors will be addressed in the following sections.

\section{Program Setting and Curriculum}

The settings in which CBI is found vary tremendously in terms of their educational and social contexts, including the roles of the students' first language (L1) and the target language (TL) within the given society, as well as the institutional and community support for language education. Accordingly, students' and teachers' needs, goals, and expectations for CBI vary greatly. CBI curricula thus vary in the way in which they balance the focus between language and content. Different emphases in curricula in turn influence the types of syllabi, lessons, activities, and materials that are employed in CBI, as well as how students' and teachers' roles are defined in such instruction (Davison \& Williams, 2001).

A number of studies indicate the effectiveness of CBI in immersion programs. Canadian immersion students of L2 French outperformed their nonimmersion peers in L1 (English) by Grade 6; they performed equally well in content (math) at Grade 3, but outperformed their peers at Grade 6 (Turnbull, Lapkin, \& Hart, 2001; also see studies in Wesche, 2001). Unfortunately, however, we still have very limited controlled empirical research that systematically compares the effectiveness of CBI with other existing general language and literacy programs in different settings. Certainly, neither program type nor a strong educational environment guarantees positive results for CBI programs.

\section{Characteristics of the Teachers}

Currently, CBI is conducted by different types of teachers: some CBI programs are taught by language teachers, others are led by content 
teachers, and many are conducted with the collaboration of both types of teachers. Similarly, some teachers are native speakers of the target language and others are nonnative speakers. While it has been stressed that developing an appropriate and effective relationship between teachers and students is important in second language acquisition (Morris \& Tarone, 2003), there are some indications that students in mainstream classes in ESL contexts attribute a lower status to language teachers than to content teachers (e.g., Creese, 2002). Although teamwork has often been found to be a key condition for successful CBI implementation (Gilzow \& Branaman, 2000), the collaboration between language teachers and content teachers is often reported to be very challenging. This is partly due to the different goals that the two types of teachers set in CBI programs (Leung, 2001).

Previous research on CBI programs has assumed that the following teacher qualities influence the effectiveness of CBI programs: (a) teachers' proficiency in English or the target language (this includes not only the ability to explain content matters in English but also sufficient command to manage the class in English), (b) teachers' content knowledge, (c) teachers' instructional strategies (which includes strategies specialized for the content matter as well as general instructional strategies), and (d) teachers' attitudes including their expectations for student achievement. However, the exact relationship between these qualities and students' performance in CBI is still not well understood.

\section{Characteristics of the Learners}

Students also vary in terms of: (a) their proficiency in the target language, (b) their background knowledge of the content being instructed, (c) the learning strategies and styles they have acquired, (d) their age and level of cognitive development, and (e) their motivation and anxiety levels. Klee and Tedick (1997), for example, reported that, in their college-level content-based foreign language immersion program, students with proficiency lower than Intermediate-High ACTFL experienced "extreme frustration" (p. 155) and performed poorly or even dropped out of the program. However, as Stryker and Leaver (1997) argue, this does not necessarily mean that CBI is inappropriate for beginning-level language learners. Rather, it means that students are unlikely to perform well if their language proficiency (academic language proficiency in particular), cognitive schemata, developmental levels, and learning styles do not match the curriculum and instruction given in the CBI program in question. 


\section{Resource Availability}

Resource availability also influences the success of a given CBI program. The most important resources include: (a) collaboration among teachers, administrative staff, parents, and community, (b) allocation of time and money, and (c) preparation of textbooks and other kinds of material. Numerous reports from different CBI settings stress the importance of institutional collaboration and both human and financial support for the program (e.g., Gilzow \& Branaman, 2000; Stryker \& Leaver, 1997). The adjunct model used at UCLA not only entails substantial collaboration between content and language teachers but also includes other types of collaboration including a network of tutorial and counseling services available outside of the classroom (Snow \& Brinton, 1988).

It is not always easy to prepare authentic materials that are appropriate for the students' linguistic and cognitive needs as well as suited to their interests. In foreign language education contexts, imported textbooks may not match well with existing local curricula or national standards. The content of certain "authentic" material may also be far too unfamiliar to such students. In some programs, teachers have accordingly provided students with background reading in their L1, and this has frequently been found to be effective (e.g., Sternfeld, 1997).

\section{Considerations Needed for Implementing CBI in EFL Contexts}

So far, we have seen the various factors that influence the effectiveness of CBI. In this section, I argue that the challenge of implementation of $\mathrm{CBI}$ in EFL contexts requires careful consideration and tremendous commitment by teachers, administrative staff, and others. I will make a number of suggestions for those who are considering implementing CBI in EFL contexts.

\section{The Importance of Needs Analysis}

Before implementing CBI, a series of needs analyses is indispensable. Program goals and student needs should be specified, and then one needs to examine whether CBI would be the best approach to meet these needs. One of the most important questions to be addressed has to do with the balance between language and content in the curriculum.

In EFL programs, the goals and motivation for implementing CBI are often very different from those of immersion programs and ESL programs (e.g., sheltered programs). In many immersion and ESL programs, 
the curriculum is mainly driven by the content, and it is therefore not surprising to see teachers' attention and discourse centered on content rather than language (Short, 2002). ESL students are often expected to merge into mainstream content classes as efficiently and quickly as possible. However, in EFL contexts, the main motivation for employing $\mathrm{CBI}$ is to provide students with optimal and meaningful input through content so that they can develop an adequate use of the target language. Therefore, the curriculum is largely driven by language criteria and development. In fact, in East Asia the most popular CBI approaches currently employed are theme-based instruction and ESP, or what Davison and Williams (2001) call "contexualized language teaching" (p. 58).

There are a number of issues that are often ignored in CBI in EFL contexts. First, based on my own observations and interviews with teachers who employ CBI in EFL contexts, there appears to be a widespread assumption that providing meaningful input through content is a sufficient base for adequate language development. However, such an assumption does not necessarily hold true. It is well documented that comprehensible input alone is not sufficient for adequate language development (e.g., Swain, 1985, 1993). Close examination of the interaction between teachers and students in CBI classes has revealed that teachers' feedback is overwhelmingly on content rather than language, and that the learners have little opportunity to notice subtle mistakes in their language use through interacting with the teacher (Pica, 2002; Pica \& Washburn, 2002; Swain, 1988). Stryker and Leaver (1997) reported that their college level adult foreign language learners "wanted and needed" to explicitly deal with grammar in their CBI programs (p. 299). As described in Ballman's (1997) "content-enriched instruction" for beginning-level foreign language learners, vocabulary and grammar instruction as well as content need to be systematically integrated. Davison and Williams (2001) state that "a content curriculum, no matter how effective or interesting, does not necessarily lead to comprehensive language development" (p. 65). If the primary goal of instruction is language development rather than content learning (which is mainly the case in EFL contexts), conscious efforts to design and employ appropriate curricula, tasks, instructional strategies, and assessment are necessary in order to facilitate students' language learning.

Second, one should keep in mind that it is difficult to select both content and language topics and order them in such a way that they are meaningful and appropriate for students. Language functions and forms vary according to the content. In language-focused CBI programs, 
I have often observed that content selection which is driven by the language function and developmental sequence results in the selection of fragmented and unrelated content topics. It is also not uncommon for language teachers (or homeroom teachers in the case of elementary schools) to choose topics that they themselves are most comfortable with teaching or that their students may be exposed to in other subjects. While there certainly is substantial merit in choosing topics that students are interested in or familiar with, teachers also must pay close attention to how systematically and consistently students can be exposed to language functions and forms through various topics and content. Since the systematic and repeated use of language will facilitate learners' language acquisition, the curriculum needs to be organized in "spiral" forms so that students are exposed to the same linguistic components systematically and repeatedly. This requires close collaboration between curriculum developers, language teachers, and content teachers.

Lastly, in EFL contexts, there appears to be insufficient discussion as to why content matter has to be offered in the students' foreign language in the first place, especially if the content is new and unfamiliar to the students. In ESL contexts, students and teachers have clear goals: for example, to quickly acquire sufficient academic language proficiency and learning strategies in order to catch up with native speakers in mainstream classrooms. CBI can be an effective approach in helping students attain such goals. However, many EFL students in East Asia do not appear to have such pressing needs to acquire academic language proficiency and learning strategies in a foreign language as their ESL counterparts do.

There is abundant evidence showing that providing content (or the background of the content in question) in students' L1 will facilitate their content learning in their target language, and many ESL programs and bilingual programs adopt this strategy. In East Asian EFL contexts where students usually share the same L1, one can easily assume that most content would be more efficiently acquired in the students' L1 rather than in their target language. Moreover, the majority of the students in East Asia have to take entrance examinations in select core subjects in their first language rather than in a foreign language in order to gain access to higher education. In other words, students often cannot find any particular reason to learn such subjects in English, and some may be frustrated by their lack of ability to digest instruction and materials for high-stakes subjects provided in English.

While Canadian immersion programs have shown that immersion students had an advantage in the mastery of certain content (such as 
math) (e.g., Bournot-Trites \& Reeder, 2001), such positive results appear to depend on students' high proficiency in the target language. In fact, a later immersion program in Hong Kong showed a negative effect on the students' math scores (March, Hau, \& Kong, 2000), and this may be due in part to the students' lower English proficiency as well as Hong Kong's social and educational context, which is very different from Canada's. As with the case of the Chinese high school chemistry students described in the first episode of the introduction to this paper, EFL students may be overwhelmed linguistically, cognitively, and emotionally by the amount of information in a high-stakes subject. To make matters worse, they also might not see why they need to learn subject matter in a foreign language in the first place. We must be careful when examining the pros and cons of introducing content in a foreign language that is either entirely new to students or considered high stakes.

\section{Sufficient Support for Teachers}

Content teachers not only require a sufficient level of English proficiency, but also need a fair amount of information on language development and language use in the given content, as well as an awareness of students' proficiency levels and language learning strategies. Similarly, language teachers who wish to employ CBI should have sufficient content knowledge and strategies to teach the content in question, as well as knowledge about language use in the given content domain.

However, in many East Asian EFL contexts, such teacher qualifications are not guaranteed. As can be seen in the newly introduced bilingual program described in the second episode of the introduction to this paper, it is not unusual in East Asia to hire native English speaking teachers solely on the basis of their (assumed) language proficiency, even though such teachers may not have sufficient content knowledge. Moreover, the strategies needed to teach a particular content subject may differ depending on the cultural and school environment (e.g., pressure from entrance examinations). This could present a potential challenge for teachers who are not familiar with the local environment. Similarly, the overwhelming majority of local content teachers (as well as local English teachers in some cases) do not have sufficient proficiency in English and other language-related knowledge, as mentioned above, to handle teaching content in English. On top of all of this, content teachers and language teachers have little time to negotiate between themselves how to develop and implement CBI together. 
Therefore, in implementing CBI in EFL contexts, it is crucially important to provide teachers with systematic support to help them develop such knowledge and strategies and to secure ample time for collaboration. There have been some informal efforts among teachers in East Asia; for example, I observed some language teachers giving English lessons to content teachers (such as teaching them a minimal amount of classroom English), and I have also observed some language teachers sitting through content classes in order to familiarize themselves with such content. However, this is far from sufficient; it is necessary to provide both language and content teachers with systematic support so that they can address their weaknesses, negotiate the goals of CBI, and make effective collaboration possible.

\section{Careful Monitoring of Student Learning and Awareness of Potential Problems}

Students may face different kinds of challenges in CBI programs depending on their characteristics, as mentioned in the previous section. In order to meet the diverse needs of students, it is necessary to carefully monitor their learning and any problems they may face in this regard. Although language and content can be hard to separate, assessments for CBI need to identify whether insufficient performance in CBI tasks is due mainly to lack of language proficiency or to lack of background knowledge of the content. It is also necessary to control the nonlinguistic aspects of CBI tasks throughout the program so that the students' language development is monitored consistently and systematically.

In reality, however, this is much more difficult to do than one might expect. Since EFL students typically have very limited exposure to the target language in general, they might not have the necessary linguistic proficiency to deal with content that is appropriate for their cognitive levels, and they tend to depend on their L1 to understand the content. In CBI classes, it is assumed that only the target language is used in the class. And indeed, if the primary focus of the curriculum is on foreign language development, students' frequent use of L1 during tasks is a serious concern.

Depending on the students' needs, however, their L1 may be used subject to certain conditions. In foreign language contexts, some programs allow students with lower proficiency to respond to the teachers' questions in their L1. Another common strategy used in foreign language $\mathrm{CBI}$ classes is to provide students with content background readings in 
their L1 in order to facilitate content learning in their foreign language (Sternfeld, 1997). The use of students' L1 may also help reduce stress and anxiety among certain students.

While we may be able to effectively utilize the students' L1 under certain limited conditions, we should also bear in mind that the extent to which students' L1 should be permitted in CBI classes is debatable. As shown in the episode above in which elementary school students were given a "kimpa-making" task, allowing students excessive access to their L1 during class can prevent them from receiving meaningful and comprehensive input in the target language. Teachers' unplanned, excessive use of the students' L1, such as routinely translating instructions into the students' L1 (as we can see in the example of the Chinese chemistry class cited in the introduction to this paper) can also lead students to not pay enough attention to the target language and therefore deprive them of receiving input in the target language. If the students have to depend heavily on their L1 to digest the content, then it is reasonable to conclude that introducing the particular content in question is inappropriate in terms of both their foreign language development and their content learning.

\section{Securing Sufficient Resources}

The effectiveness of CBI is greatly influenced by various types of resources as discussed above. In East Asian EFL contexts, it is not uncommon for schools to start introducing CBI without securing sufficient funding, without school-wide and parental support, and without sufficient time for negotiation and preparation of curriculum and teaching material. As discussed above, the selection of linguistic and content topics is not an easy task, and imported textbooks are often not suitable for the students' needs. In the Bridge Program in Hong Kong (Goldstein \& Liu, 1994), tremendous efforts were made to develop a spiral curriculum across content domains; students were exposed to linguistic forms systematically and repeatedly in multiple subjects. Without such commitment and support, CBI cannot be expected to produce positive results.

\section{Conclusion}

CBI in English does not entail simply offering content subjects in English as opposed to the students' L1. One cannot assume that language acquisition takes place incidentally as long as meaningful content 
is provided. Instead, a number of factors determine the success of CBI. CBI can be successfully implemented in EFL contexts, but careful consideration and planning are necessary. The primary focus in EFL is usually foreign language development; CBI curricula have to be developed in light of that goal. Perhaps, in making the decision to employ CBI in EFL contexts, we should keep in mind that "not all good content teaching is necessarily good language teaching" (Swain, 1988, p. 68).

\section{Acknowledgement}

This study was partially supported by a Postdoctoral Fellowship from the National Academy of Education in the US and the Spencer Foundation awarded to the author in 2004-2005. Part of the study was presented at the Korean Association of Teachers of English (KATE) 2005 International Conference held in June 2005 in Seoul, South Korea. I am grateful to the editors and the two anonymous reviewers who provided helpful feedback on an earlier version of this paper.

\section{References}

Anderson, J. R. (1990). Cognitive psychology and its implications. New York: W. H. Freeman.

Armbruster, B. (1996). Schema theory and the design of content-area textbooks. Educational Psychologist, 21, 253-276.

Ballman, T. L. (1997). Enhancing beginning language courses through contentenriched instruction. Foreign Language Annals, 30 (2), 173-181.

Bournot-Trites, M., \& Reeder, K. (2001). Interdependence revisited: Mathematics achievement in an intensified French immersion program. The Canadian Modern Language Journal, 58 (1), 27-43.

Brinton, D. M., Snow, M. A., \& Wesche, M. B. (2003). Content-based second language instruction. Ann Arbor, MI: University of Michigan Press.

Chamot, A. U., \& O'Malley, J. M. (1994). The CALLA handbook: Implementing the cognitive academic language learning approach. Reading, MA: AddisonWesley.

Creese, A. (2002). The discursive construction of power in teacher partnerships: Language and subject specialists in mainstream schools. TESOL Quarterly, 36 (4), 597-616.

Cummins, J. (1992). Language proficiency, bilingualism, and academic achievement. In P. Richard-Amato \& M. A. Snow (Eds.), The multicultural classroom: Readings for content-area teachers (pp. 16-26). New York: Longman. 
Davies, S. (2003). Content-based instruction in EFL contexts. The Internet TESL Journal, 4 (2). Retrieved March 15, 2004, from http://iteslj.org/Articles/ Davies-CBI.html.

Davison, C., \& Williams, A. (2001). Integrating language and content: Unresolved issues. In B. Mohan, C. Leung, \& C. Davison (Eds.), English as a second language in the mainstream: Teaching, learning and diversity (pp. 51-90). Harlow, UK: Pearson.

Echevarria, J., Vogt, M., \& Short, D. J. (2004). Making content comprehensible for English language learners: The SIOP model. Needham Heights, MA: Allyn \& Bacon.

Gilzow, D., \& Branaman, L. E. (2000). Lessons learned: Model early foreign language programs. Washington, DC: Center for Applied Linguistics and McHenry, IL: Delta Systems.

Goldstein, L., \& Liu, N. (1994). An integrated approach to the design of an immersion program. TESOL Quarterly, 28 (4), 705-725.

Johns, A. M. (1997). English for specific purposes and content-based instruction: What is the relationship? In M. A. Snow \& D. M. Brinton (Eds.), The contentbased classroom: Perspectives on integrating language and content (pp. 363-366). New York: Longman.

Kasper, L. F. (1997). The impact of context-based instruction programs on the academic progress of ESL students. English for Specific Purposes, 16, 309320.

Klee, C. A., \& Tedick, D. J. (1997). The undergraduate foreign language immersion program in Spanish at the University of Minnesota. In S. B. Stryker \& B. L. Leaver (Eds.), Content-based instruction in foreign language education (pp. 140-173). Washington, DC: Georgetown University Press.

Krashen, S. (1985). The input hypothesis: Issues and implications. New York: Longman.

Langman, J. (2003). The effects of ESL-trained content-area teachers: Reducing middle-school students to incidental language learners. Prospect, 18 (1), 1426.

Leung, C. (2001). Evaluation of content-language learning in the mainstream classroom. In B. Mohan, C. Leung, \& C. Davison (Eds.), English as a second language in the mainstream: Teaching learning and identity (pp. 177-198). New York: Longman.

March, H. W., Hau, K. T., \& Kong, C. K. (2000). Late immersion and language of instruction in Hong Kong high schools: Achievement growth in language and nonlanguage subjects. Harvard Educational Review, 7 (3), 303-346.

Met, M. (1998). Curriculum decision-making in content-based language teaching. In J. Cenoz \& F. Genesee (Eds.), Beyond bilingualism: Multilingualism and multilingual education (pp. 35-63). Philadelphia, PA: Multilingual Matters.

Mohan, B. (1986). Language and content. Reading, MA: Addison-Wesley. 
Morris, F. A., \& Tarone, E. E. (2003). Impact of classroom dynamics on the effectiveness of recasts in second language acquisition. Language Learning, 53 (2), 325-368.

Murphy, J. M., \& Stoller, F. L. (2001). Sustained-content language teaching: An emerging definition. TESOL Journal, 10 (2/3), 3-5.

Pally, M. (Ed.). (2000). Sustained content teaching in academic ESL/EFL. Boston, MA: Houghton Mifflin.

Pica, T. (2002). Subject-matter content: How does it assist the interactional and linguistic needs of classroom language learners? The Modern Language Journal, 81, 1-19.

Pica, T., \& Washburn, G. (2002). Negative evidence in language classroom activities: A study of its availability and accessibility to language learners. Working Papers in Educational Linguistics, 18 (1), 1-28.

Ryding, K., \& Stowasser, B. (1997). Text development for content-based instruction in Arabic. In S. B. Stryker \& B. L. Leaver (Eds.), Content-based instruction in foreign language education (pp. 107-118). Washington, DC: Georgetown University Press.

Short, D. J. (2002). Language learning in sheltered social studies classes. TESOL Journal, 11 (1), 18-24.

Snow, M., \& Brinton, D. (1988). Content-based instruction: Investigating the effectiveness of the adjunct model. TESOL Quarterly, 22, 553-574.

Sternfeld, S. R. (1997). Caterpillars into butterflies: Content-based instruction in a first year Italian course. In S. B. Stryker \& B. L. Leaver (Eds.), Content-based instruction in foreign language education (pp. 56-77). Washington, DC: Georgetown University Press.

Stoller, F. L. (2004). Content-based instruction: Perspectives on curriculum planning. Annual Review of Applied Linguistics, 24, 261-283.

Strevens, P. (1992). English as an international language: Directions in the 1990s. In B. Kachru (Ed.), The other tongue: English across cultures (pp. 27-47). Urbana: University of Illinois Press.

Stryker, S. B. (1997). The Mexico experiment at the Foreign Service Institute. In S. B. Stryker \& B. L. Leaver (Eds.), Content-based instruction in foreign language education (pp. 177-202). Washington, DC: Georgetown University Press.

Stryker, S. B., \& Leaver, B. L. (1997). Content-based instruction: Some lessons and implications. In S. B. Stryker \& B. L. Leaver (Eds.), Content-based instruction in foreign language education (pp. 285-312). Washington, DC: Georgetown University Press.

Swain, M. (1985). Communicative competence: The role of comprehensible input and comprehensible output in its development. In S. Gass \& C. Madden (Eds.), Input and second language acquisition. Rowley, MA: Newbury House.

Swain, M. (1988). Manipulating and complementing content teaching to maximize second language learning. TESL Canada Journal, 6, 68-83. 
Swain, M. (1993). The output hypothesis: Just speaking and writing aren't enough. The Canadian Modern Language Review, 50, 158-164.

Turnbull, M., Lapkin, M., \& Hart, D. (2001). Grade 3 immersion students' performances in literacy and mathematics: Province-wide results from Ontario (1998-99). The Canadian Modern Language Review, 58 (19), 9-26.

Wesche, M. B. (Ed.). (2001). Special Issue: French immersion and content-based language teaching in Canada. The Canadian Modern Language Review, 58 (1).

Willis, A. S. (1998). Feasibility of content-based instruction in Japanese foreign language courses: Some questions to ask. Studies in International Relations (Intercultural Relations), 19 (1), 39-60. 
Appendix. Educational contexts where CBI has been implemented

\begin{tabular}{|c|c|c|}
\hline & \multicolumn{2}{|c|}{ Context of language learning } \\
\hline & Second language contexts & $\begin{array}{l}\text { Foreign language } \\
\text { contexts }\end{array}$ \\
\hline & \multicolumn{2}{|c|}{ Primary \& secondary level } \\
\hline 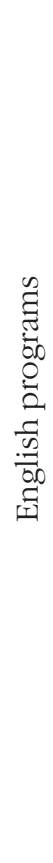 & $\begin{array}{l}\text { ESL teachers may be able to introduce } \\
\text { content-area material (e.g. math, science) } \\
\text { in their classes in order to help English } \\
\text { learning (EL) students make a smoother } \\
\text { transition to mainstream classrooms. The } \\
\text { instruction may include technical vocabu- } \\
\text { lary teaching and various strategies to } \\
\text { comprehend textbooks. The way in which } \\
\text { CBI is implemented by ESL teachers varies } \\
\text { from school to school and from program } \\
\text { to program. Theme-based instruction } \\
\text { is one type of CBI which is widely im- } \\
\text { plemented in many ESL programs. (In } \\
\text { theme-based instruction, more focus may } \\
\text { be placed on helping students develop } \\
\text { general academic language skills in their } \\
\text { L2, rather than mastering the subject mat- } \\
\text { ter per se). The Cognitive Academic Lan- } \\
\text { guage Learning Approach (CALLA) is an } \\
\text { instructional approach which integrates } \\
\text { language, content, and learning strategies } \\
\text { into a traditional ESL approach (Chamot \& } \\
\text { O' Malley, 1994) }{ }^{1} \text {. }\end{array}$ & $\begin{array}{l}\text { Recently, CBI (and } \\
\text { theme-based instruction } \\
\text { in particular) has gained } \\
\text { more popularity in the } \\
\text { curriculum. }\end{array}$ \\
\hline
\end{tabular}

Postsecondary level

At the college level, ESL classes often employ CBI in order to prepare students for academic work. English for specific purposes (ESP) and English for academic purposes (EAP) can be considered as types of CBI, and the latter includes instruction on strategies on how to read academic articles, write academic papers, and so forth. ${ }^{2}$ ESL programs also may employ sustained content language teaching $(\text { SCLT })^{3}$ in which a single content subject
A growing number of college-level courses incorporate $\mathrm{CBI}$ in EFL contexts. As in many ESL contexts, themebased instruction and courses teaching ESP are popular. Subject matter courses may be offered exclusively in English in certain contexts 
(e.g., "American History") is chosen and studied over time (e.g., Pally, 2000). CBI has also been implemented in vocationoriented ESL programs. In the adjunct model, content-area teachers and ESL teachers are paired and teach the content class and the adjacent ESL class separately (e.g., the Summer Freshman Program at $\mathrm{UCLA}^{4}$ ). (The SCLT and the adjunct model also have been implemented at both the secondary level as well as in EFL contexts.) (e.g., business management classes offered in English for English and/or business major students). As in the ESL context, the adjunct model also has been employed. Various professional development programs also have employed CBI.

Primary \& secondary level in ESL contexts

In bilingual programs for EL students, content subjects are taught by bilingual teachers in the students' L1s and/or their L2s (i.e., English). In the sheltered content model, which is most commonly implemented in immersion programs, EL students are grouped together and learn content subjects separately from mainstream students 5 . The sheltered content classes are usually taught by trained bilingual teachers and/or content-area teachers in bilingual programs. The teachers use various instructional strategies and may modify material in order to make content subject instruction comprehensible for these students. The sheltered model has been adapted in ESL programs as well. The Sheltered Instruction Observation Protocol (SIOP) model is a type of sheltered instructional approach developed by researchers at the Center for Applied Linguistics (Echevarria, Vogt, \& Short, 2004). CBI also has been implemented in two-way immersion programs where both EL students and native English-speaking students study together.
Due to a growing interest in bilingual education in many EFL contexts, CBI has gained much attention. However, its implementation is still relatively limited and the way in which CBI has been implemented varies from program to program.

Immersion programs at the primary and secondary level in Canada:

Content subjects are taught in the students' L2 (French) as well as language instruction for the L2 itself. The types of immersion programs in Canada vary. Some content subjects may be taught in the students' L1 (English) from an earlier grade or may be delayed until a later stage. 


\begin{tabular}{|c|c|c|}
\hline & Heritage language programs & $\begin{array}{l}\text { Foreign language pro- } \\
\text { grams }\end{array}$ \\
\hline 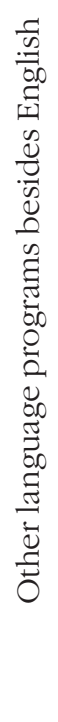 & $\begin{array}{l}\text { CBI is employed in various types of herit- } \\
\text { age language programs, such as weekend } \\
\text { school programs for immigrant children } \\
\text { (e.g., "Korean History" in Korean for Ko- } \\
\text { rean-American students whose primary } \\
\text { language might be English). }\end{array}$ & $\begin{array}{l}\text { CBI has been used in } \\
\text { foreign language pro- } \\
\text { grams from the primary } \\
\text { to the post-secondary } \\
\text { level (e.g., the "Italian } \\
\text { literature," "Italian arts," } \\
\text { and "Italian politics," } \\
\text { classes that may be of- } \\
\text { fered in Italian by the } \\
\text { Italian language depart- } \\
\text { ment at a given college). } \\
\text { Foreign Language Across } \\
\text { Curriculum (FLAC) is in- } \\
\text { creasingly popular. CBI } \\
\text { may also be employed } \\
\text { in vocational and pro- } \\
\text { fessional training that } \\
\text { is conducted in the stu- } \\
\text { dents' foreign language. }\end{array}$ \\
\hline
\end{tabular}

Notes:

1. In addition to CALLA, a few other approaches have been suggested.

2. There are some researchers who consider ESP distinct from CBI (e.g., Johns, 1997; Willis, 1998).

3. SCLT is employed within language teaching contexts and has the following two characteristics: it has "a focus on the exploration of a single content area, or carrier topic" and "a complementary focus on L2 learning and teaching” (Murphy \& Stoller, 2001, p. 3). Therefore, one can consider the sheltered and adjunct models as containing elements of SCLT. Murphy and Stoller (2001) indicate the need for articulating "a clearer definition of SCLT" (p. 4).

4. See Brinton, Snow, and Wesche (2003) and Snow and Brinton (1988) for details.

5. California has officially employed a sheltered model, Specifically Designed Academic Instruction in English (Echevarria, Vogt, \& Short, 2004) 